\title{
Incidence and detection of parasitic infections by cyst and ova on fruits and vegetables from different major markets in K ogi, Nigeria
}

\author{
O. S. Omowaye* and P.A. Audu \\ *Department of Biological Science, Kogi State University, Anyigba, NIGERIA \\ ${ }^{1}$ Department of Biological Science,University of Agriculture, Makurdi, Benue State, NIGERIA \\ *Corresponding author. E-mail: Jesuniyi4wealth@yahoo.com
}

\begin{abstract}
In the course of a study of parasitic infections by cyst and ova on fruits and vegetable sold in middle-belt Nigeria, three different major public markets was selected. Six different fruits and vegetables total to 2406 samples were examined.Data obtained were statistically analyzed using anova for the level of significance difference where appropriate. Of the 1755 fruits examined, $4.3 \%$ were positive for parasites ova and $2.5 \%$ for cysts. Of the 761 vegetables examined, $4.6 \%$ were positive for parasites ova and $2.8 \%$ for cysts. The contamination rate of protozoan cyst and ova found are Giardia lamblia (2.61\%) Entamoebs histolytica $(0.66 \%)$. The difference was not statistically significant $(p>0.05)$. Cases of contamination rate of protozoan cyst and ova were small compared to helminthic contamination. However, helminths such as Strongylodies stercoralis Trichiuris trachura and Ascaris lumbricoides were predominant in that order. The public health implication on the subjects is discussed. Through washing of all fruits and vegetables with clean water prior to consumption is recommended.
\end{abstract}

Keywords: Cysts, Fruits, Helminths, Ova, Vegetables

\section{INTRODUCTION}

Parasites can contaminates crops through various routes for examples, via water contaminated by faeces that is used for irrigation or spraying of crops, by poor personal hygiene practices among pickers or handlers of crops, by contact with contaminated soil or by contact with faeces of wild animals (David, 2005) . The contamination of vegetables by parasites has long been established. Amongst the classes incriminated are Protozoa, Cestodes, Trematodes and Nematodes (Kogi et al., 1991, Umeche, 1991 and Okoronkwo, 2000). The research of this magnitude is therefore necessary in order to determine the prevalence and types of parasites found on vegetables and fruits in the study areas. And this will give room for the management of fruits and vegetables by the consumers before consumption.

\section{MATERIALS AND METHODS}

Study area: The study areas covered were Anyigba (in Dekina Local Government Area), Bassa (in Bassa Local Government Area) and Dekina (in Dekina Local Government Area) of Kogi State. Anyigba is located in the North-Eastern part of Egume township. It lies approximately between longitude $7^{\circ} 36^{\prime} \mathrm{N}$ and latitude $7^{\circ} 12^{\prime} \mathrm{E}$ and is bordered to the south by Ojikpadala, to the North by Odu-Iyale and to the west by Ogbabede township. It is densely populated and is a university township, residential as well as commercial centre.

The market where the research is carried out is located at heart of the town itself. The market operate on every five days and quite a number of people within the L.G.A. and environs patronize the market to make purchases.

Bassa Local Government having a population of 404,777 as at 1991 census projection for Simon Shaba Abu is situated along longitude $6^{0} 36^{\prime} \mathrm{E}$ and $7^{0} 30$ 'E and latitude $7^{\circ} 30^{\prime} \mathrm{E}$ And $8^{\prime} 05^{\circ} \mathrm{N}$ and is bounded the east by Oganenigwu, on the west by Adavi, on the north by Ijumu L.G.A. and on the south by Dekina L.G.A. The local government is not very large compared to Dekina L.G.A. A great number of activities usually associated with most of the township go on in the local government. The sanitary condition of the environment is extremely poor, because majority of the inhabitants are farmers, artisan workers and traders. Farmlands are used as toilets, as there are few public and even private toilet systems in some areas. Some fishing activity also goes on there and at the end of the days work, the farmers take their bath at the banks of the river and wash their produce before taking to the market.

Dekina is located in the north-eastern part of Odu-Iyale township. It lies approximately between longitude $6^{\circ} 36^{\prime} \mathrm{E}$ and latitude $7^{\circ} 30^{\prime} \mathrm{E}$ and is bordered to the west by Ofu township, to the north by Bassa L.G.A. and to the southeast by Ankpa township. It is the headquarter hometown of Dekina L.G.A. the largest L.G.A. in Nigeria in term of land mass. It is sparsely populated and is residential and majority of the dwellers are local farmers and traders. There are old houses, most of which do not have soaker 
way pits and so the body wastes of the residents are discharged directly into the drain. The same drain or river, sellers of fruits, vegetables and crops wash them before taking them straight to the markets.

Sample collection: The fruits and vegetables were bought from the trader in these three markets the 006 to 11.00 hours in the morning. Fruits includes Carica papaya (pawpaw), M usa sapientum (banana), Lycopersieum esculentum (tomato) and Citrus sinensis (orange). The vegetables are Amarathanthus cruentus (green vegetable), Telferiria occidentalis (pumpkin leave), Talinum triangulare (water leaf) and Lectus sativa (lettuce). The fruits and vegetables were collected into sterile, labelled polythene bags and transported to the laboratory for examination for helminth ova and larvae within 6 hours of collection.

Sample processing: $100 \mathrm{~g}$ of each types of fruits and vegetable were washed in $360 \mathrm{ml}$ of distilled water. Each suspension was strained through a piece of double layered sieve, which filtered off coarse sandy particles but allowed the passage of helminth ova, cyst and larvae. The filtrate was centrifuged at $2500 \mathrm{rpm}$ for one minute. The supernatants were poured off from the different tubes to leave only the sediment. The sediment from each tube was checked for helminth ova, cyst and larvae by the concentration technique as described by Umeche (1991) and Cheesbrough (1998), was used for the identification of the ova and larvae observed.

Statistical analysis: Chi-square $\left(\mathrm{x}^{2}\right)$ test and ANOVA was used to determine whether any relationship exists between geohelminthic ova/larvae and contamination of different fruits and vegetables, type of produce and location of markets.

\section{RESULTS}

Six different varieties of fruits comprising M. Sapietum (banana), L. esculentum (tomato), C. sinensis (orange), S. melongena (egg plant) A. esculentus (Okra) and P. nigrum (pepper) were collected from markets.

Overall, a total of 1755 fruits varieties were examined. Six different species of vegetables comprising A. craentus (green vegetables), T. occidentalis (pumpkin leaf), T. trangulare (water leaf), Vernoma species (Bitter leaf), A. cepa (Onion) and C. olitorus (jute leaf) were collected from markets.Overall, a total of 671 vegetables species were examined.

Bassa market was considered the highest helmiths detection. It was more than two times more contaminated

Table 1. Distribution of Helminths cysts, Ova/Larvae on fruits and vegetables in Anyigba, Bassa and Dekina Markets local Government Area Kogi State (\% given in paranthesis).

\begin{tabular}{|c|c|c|c|c|c|c|}
\hline \multirow{3}{*}{$\begin{array}{l}\text { Fruits and } \\
\text { V egetables } \\
\text { Fruits }\end{array}$} & \multicolumn{6}{|c|}{ Study area } \\
\hline & \multicolumn{2}{|c|}{ Anyigba } & \multicolumn{2}{|c|}{ Bassa } & \multicolumn{2}{|c|}{ Dekina } \\
\hline & Total examined & $(\%)(+\mathrm{ve})$ & Total examined & $(\%)(+\mathrm{ve})$ & Total examined & $(\%)(+\mathrm{ve})$ \\
\hline $\begin{array}{l}\text { C. Sinesis } \\
\text { (Orange) }\end{array}$ & 61 & $6(9.84)$ & 15 & $0(0)$ & 21 & $6(28.57)$ \\
\hline $\begin{array}{l}\text { S. melangena } \\
\text { (Egg plant)) }\end{array}$ & 87 & $1(1.15)$ & 141 & $12(8.51)$ & 120 & $7(5.83)$ \\
\hline $\begin{array}{l}\text { M. Sapietum } \\
\text { (Banana) }\end{array}$ & 149 & $26(1.75)$ & 133 & $1(0.75)$ & 51 & $6(11.76)$ \\
\hline $\begin{array}{l}\text { A. esculentus } \\
\text { (Okra) }\end{array}$ & 120 & $2(1.673)$ & 174 & $10(5.75)$ & 120 & $10(8.33)$ \\
\hline $\begin{array}{l}\text { L. escalentum } \\
\text { (Tomato) }\end{array}$ & 50 & $4(8.00)$ & 100 & $10(10.00)$ & 101 & $6(6.94)$ \\
\hline $\begin{array}{l}\text { P. nigrum } \\
\text { (Black Pepper) }\end{array}$ & 83 & $26(31.33)$ & 68 & $13(19.12)$ & 161 & $41(25.47)$ \\
\hline V egetables & & & & & & \\
\hline $\begin{array}{l}\text { A. cepa } \\
\text { (Onion) }\end{array}$ & 51 & $1(1.96)$ & 40 & $11(27.5)$ & 100 & $7(7.00)$ \\
\hline $\begin{array}{l}\text { T. occidentals } \\
\text { (Pumpkin Leaf) }\end{array}$ & 30 & $1(3.33)$ & 30 & $0(0)$ & 30 & $1(33.33)$ \\
\hline $\begin{array}{l}\text { Vernonia Species } \\
\text { (Bitter leaf) }\end{array}$ & 30 & $1(3.33)$ & 30 & $13(43.33)$ & 30 & $26(86.67)$ \\
\hline $\begin{array}{l}\text { A. cruentus } \\
\text { (Green Vegetable) }\end{array}$ & 50 & $1(2.00)$ & 50 & $-(0)$ & -50 & $2(4.00)$ \\
\hline $\begin{array}{l}\text { T. trangulane } \\
\text { (Water leaf) }\end{array}$ & 50 & $0(0)$ & 50 & $6(12)$ & 50 & $4(8.00)$ \\
\hline $\begin{array}{l}\text { C. olitorus } \\
\text { (jute leaf) }\end{array}$ & - & - & 30 & $0(0)$ & - & - \\
\hline Total & 761 & $70(72.89)$ & 861 & $75(153.96)$ & 834 & $116(225.9)$ \\
\hline
\end{tabular}


Table 2. Distribution of protozoan cysts, ova/larvae on fruits and vegetables in Anyigba, Bassa and Dekina markets local Government area Kogi State.

\begin{tabular}{|c|c|c|c|c|c|c|}
\hline \multirow{3}{*}{$\begin{array}{l}\text { Fruits and } \\
\text { V egetables } \\
\text { Fruits }\end{array}$} & \multicolumn{6}{|c|}{ Study area: } \\
\hline & \multicolumn{2}{|c|}{ A nyigba } & \multicolumn{2}{|c|}{ Bassa } & \multicolumn{2}{|c|}{ Dekina } \\
\hline & Total examined & (\% ) (+ve) & Total examined & $(\%)$ (+ve) & Total examined & $(\%)(+v e)$ \\
\hline $\begin{array}{l}\text { C. sinesis } \\
\text { (Orange) }\end{array}$ & 61 & $5(8.10)$ & 15 & $6(40.00)$ & 21 & $0(0)$ \\
\hline $\begin{array}{l}\text { S. melangena } \\
\text { (Egg plant) }\end{array}$ & 87 & $20(2.30)$ & 141 & $0(0)$ & 120 & $0(0)$ \\
\hline $\begin{array}{l}\text { M. sapietum } \\
\text { (Banana) }\end{array}$ & 149 & $3(2.01)$ & 133 & $7(5.26)$ & 51 & $0(0)$ \\
\hline $\begin{array}{l}\text { A. esculentus } \\
\text { (Okra) }\end{array}$ & 120 & $0(0)$ & 174 & $5(2.87)$ & 120 & $0(0)$ \\
\hline $\begin{array}{l}\text { L. escalentum } \\
\text { (Tomato) }\end{array}$ & 50 & $1(2.00)$ & 100 & $0(0)$ & 101 & 1(0.99) \\
\hline $\begin{array}{l}\text { P. nigrum } \\
\text { (Black pepper) }\end{array}$ & 83 & $1(1.21)$ & 68 & $0(0)$ & 161 & $1(0.62)$ \\
\hline V egetables & & & & & & \\
\hline $\begin{array}{l}\text { A. cepa } \\
\text { (Onion) }\end{array}$ & 51 & $1(1.96)$ & 40 & $30(0)$ & 100 & $5(5.00)$ \\
\hline $\begin{array}{l}\text { T. occidentals } \\
\text { (Pumpkin Leaf) }\end{array}$ & 30 & $1(3.33)$ & 30 & $6(20: 00)$ & 30 & $0(0)$ \\
\hline $\begin{array}{l}\text { Vernonia Species } \\
\text { (Bitter leaf) }\end{array}$ & 30 & $0(0)$ & 30 & $0(0)$ & 30 & $5(16.67)$ \\
\hline $\begin{array}{l}\text { A. cruentus } \\
\text { (Green vegetable) }\end{array}$ & 50 & $1(2.00)$ & 50 & $0(0)$ & 50 & $0(0)$ \\
\hline $\begin{array}{l}\text { T. trangulane } \\
\text { (Water leaf) }\end{array}$ & 50 & $1(2.00)$ & 50 & $0(0)$ & 50 & $6(1.20)$ \\
\hline $\begin{array}{l}\text { C.olitorus } \\
\text { (jute leaf) }\end{array}$ & - & - & 30 & $0(0)$ & (0) & - \\
\hline Total & 761 & $34(24.91)$ & 861 & $24(68.13)$ & 834 & $18(24.48)$ \\
\hline
\end{tabular}

with helmiths cyst, ova and larvae compared to Dekina market in Dekina Local Government.(OR $=1.16,95 \%$ $\mathrm{CL}=0.003,0.001$ ) (Table 3 ). The most contaminated source of protozoans was the Bassa market. When compared to Anyigba market, the level of contamination was more than two times. $(\mathrm{OR}=1.17,95 \% \mathrm{CL}=0.048)$ (Table 4).

\section{DISCUSSION}

The detection of helminth and protozoan cysts, ova/ larvae on fruits and vegetables in the three study areas, has a significant public health implication. Since occurrence of oocyst was not associated with seasonality and turbidity. Putignani and Menichella (2010), Some of the vegetables and fruits are processed and eaten uncooked which could lead to infection and disease especially when served to the public.

Some of the fruits and vegetables are grown very close to the soil and prone to contamination, when eaten raw or uncooked. Beaver et al. (1953) Ascariasis and G ar diasis diseases are among the commonest parasitic and infections in Bassa local Government with considerable morbidity in pregnant women, children and adults.

No helmith or protozoan cyst or ova were detected on C. olitoris (jute leaf) examined probably because the smooth skins of the vegetable make it easy for the eggs to be washed off even with the slight washing which is usually done at the point harvest or prior to sale. Since the consumption of poorly washed vegetables is regarded as a major way for transmission of parasitic contamination (AL-Megrin and Wafa, 2010) .

In Anygba, S. melongena (egg plant) and P. nigrum (peper) were the most contaminated because the leaf tolds could retain some dirts which may not be easily remove by slight washing. In Bassa, it was a case of $L$. escul entum (tomato) and S. melongena being the most contaminated table or ground. It was discovered that, the market environment is not hygenic enough and sanitary activities was too poor.

Dekina recorded a case of S. melongena (egg plant) and P. nigrum (black pepper) as the most contaminated fruits. In all it was discovered that fruits were more contaminated than vegetables. The study has revealed a non-significant higher contamination rate of the fruits than the vegetables (P> 0. 05). This observation could be attributed to the fact that except orange and banana, the rest fruits considered were fruits- vegetable. And these were grown closer to the soil-when compared with the fruit, which 
Table 3. Showning detection of helminth cysts, ova/larvae on fruits and vegetables in Anyigba, Bassa and Dekina markets local Government area Kogi State.

\begin{tabular}{lcccc}
\hline Study area & T otal examined & No. positive & Odd ratio (OR) & 95\% Cl on odd, ratio \\
\hline Anyigba & 761 & 78 & 0.61 & $0.096-0.096$ \\
Bassa & 811 & 87 & 1.16 & $0.004-0.018$ \\
Dekina & 834 & 132 & 0.51 & $0.007-0.023$ \\
\hline Total & 2406 & 227 & 2.28 & $0.106-0.137$ \\
\hline
\end{tabular}

Table 4. Shownig detection of protozoan cysts, ova/larvae on on fruits and egetables in Anyigba, Bassa and Dekina markets local Government area Kogi State.

\begin{tabular}{lcccc}
\hline Study area & Total examined & No. positive & Odd ratio (OR) & 95\% Cl on odd, ratio \\
\hline Anyigba & 761 & 34 & 1.07 & $0.030-0.059$ \\
Bassa & 811 & 29 & 1.17 & $0.023-0.049$ \\
Dekina & 834 & 35 & 0.83 & $0.028-0.056$ \\
Total & 2406 & 98 & 3.07 & $0.151-0.164$ \\
\hline
\end{tabular}

are higher above the soil. This finding corroborates the work of Kraft (1962). Which reported that the low growth height of vegetables above soil level predisposes them to contamination with geohelminth parasite ova during flooding and heavy rain splashing. Also, the leaf folds of vegetables could retain some dirt which may not be easily removed by slight washing. More still, the smooth skins of the C. olitoris (jute leaf) and other less contaminated fruits make it easy for the ova and larvae to be washed off even with slight washing.

A. cepa (onion) was the most contaminated of the vegetables $(15.69 \%)$ followed by the T. occidentialis (pumpkin leaf) (6.67\%) in Anyigba, in Bassa both vernonia species (Bitter leaf) $(43.33 \%)$ and A. cepa (32.5\%) were the most contaminated among others. while in Dekina; Vernonia species (36.67\%) and A. cepa (15.00\%) were the most contaminated among other vegetables . the high contamination rates observed in these vegetables could be explained by their rough skins because the leaf folds could retain some dirts which may not be easily remove by slight washing by the sellers and street hawkers/ renders. C. sinensis was the most contaminated of the fruits (40.0\%) followed by P. nigrum (27.94\%) and egg plant (29.89) were the highest among other fruits. The high contamination rates could be attributed to the fact that the shades provided by the orange trees create a conducive atmosphere for indiscriminate defecation by some infected inhabitants of the communities where these fruits were harvested. Consequently, the fruits are contaminated.

The major protozoa infection highest was that of Entamoeba hisiolytica and G. lamblia. This will result to many case of entamoebiasis and gardiasis in the study of areas. As reported that fresh vegetables can be agents of transmission of protozoan cysts helminths egg and larvae (Amal et al., 2009).

The findings revealed, that helmithic parasites cyst/oval are more than protozoan parasites cyst/ova. Hence the rate of infection with intestinal helminthes generally is high among people living in dirty environments. Strongiloides stercoralis larvae, which can cause a chronic persistent infection in man especially in compromised hosts, was detected on majority of the fruits. These are Piper nigrum, M usa saplientum, C itrus sinesis and Allium cepa.

The detection of Ascaris lumbricoiudes on some fruits may promote childhood malnutrition and referred childhood growth Haling (1993). Also Beaver et al. (1953) had reported that among the geohelminths, A. lumbricoides is the most frequently encountered because the eggs are highly persistent in the environment.Another common helminthes was Trichuris trichura on fruits majorly, which has been incriminated in growth stunting even in moderately severe infections. Contamination refers in different markets show that Anyigba market had the highest rate of $15.07 \%$ followed by Dekina market with 11:93\%. The differences in contamination of fruits and vegetables among the three markets could be attributed to population increase of local sellers bring their produce to Anyigba market. Majority of these produce are being brought from sources of poor sanitary conditions and weather of the areas, although the differences were not statistically significant. Dekina market the second highest and Anyigba the highest rate enjoys a cool environment and a temperature that favour parasite ova and larvae to thrive the temperature between $22^{\circ} \mathrm{C}$ and $23^{\circ} \mathrm{C}$ favours the development of T. trichiura as well as hookworm Spp. The filthy environment and refuse heaps constitute means of contamination of fruits and vegetables even at the point of sale where these edible products are displayed. Flies can mechanically transfer parasites cyst and ova from dirt's to already displayed products.

\section{Conclusion}

This study has shown the potential risk of contracting 
helminth and protozoan infection through ingestion of unwashed, undercooked, raw/uncooked fruits and vegetables being bought from the market. These contaminations ranged from one factor to the other such as poor sanitary environment of the market, unhygienic transportation of the produce to market.

A well articulated health educational programmed with emphasis on personal and community responsibility making the environment ecologically uncondusive from the breeding and spread of the vectors of the parasites could form a subject of preaching in the church. Orientation and educational planning should be given to sellers and farmers of fruits and vegetables the need of sanitation and cleaning of their container to be free from parasitic contamination, fomites to be sterilized.

\section{REFERENCES}

Al-Megrin and Wafa, A. I. (2010).International J ournal of Tropical M edicine, 5(2): 20-23

Amal Khalifa Abougrain, Mohaamed Hadi Nahaisi, Nuri Sahli Madi Mohamed Mohamed Saied, Khalifa Sifaw Ghenghesh (2010) retrieved from www.elsevier. com /locate/foodcont. Beaver, P.C. Jung, P.C. and Cupp, E.U. (1983):Beaver, P.C. (1953). Control of soil transmitted helminthes. Am J . Trop Protozoans, and Helminthes. In: Biology and Class-
Fication, Clinical Parasitology. $9^{\text {th }}$ Edition. Beaver, P.C Jung, P.C and Cupp, E.U. (Editors). Paklin (Publisher). pp 124-128

Cheesbrought, M. (1998). Diseases. In: District laboratory practice in Tropical countries. Cheesbrough, M. (Edition). Cambridge University Press, United Kingdom. pp 185-300

David, D.(2005.) Food borne protozoan parasites. International J ournal of F ood M icrobiology, 103 : 207-227

Haling. T. (1983). Ascariasis and childhood malnutrition. Parasitology, 107: 125-136.

Kogi, E., Umoh, J.U. and Vajime, C.G. (1991). Intestinal parasites and gastroenteritis among patient attending University Clinic, Samaru, Zaria, Nigeria. The Nigeria J ournal of Parasitology, 12:77-80

Kraft, A. A., Synder, H. E. and Walter, H. W. (1962). Chemical and Biological hazards in food Lowa state, University Press Ames, pp. 226

Putignani, Lorenza and Menichella, Donato (2010). Interdisciplinaryy perspectives on infection diseases. Hindwi Publishing Corporation.

Okoronkwo, M.O. (2000). Detection and enumeration of parasitic Eggs in irrigated vegetables and salad crops in Plateau State, Nigeria.J ournal of M edical Laboratory Science 9:30-36.

Umeche, N. (1991). Parasite ova and cysts on fruits sold in Calabar, Nigeria. The Nigerian J ournal of Parasitology, 12:8587. 